\title{
ERNEST JONES AND CHARTISM C. 1856
}

SOME REMARKS IN CONNECTION WITH A LETTER OF THAT YEAR BY JONES TO HOLYOAKE

The tenth of April 1848 is usually taken for the date marking off most clearly the end of the Chartist Movement. According to the frightened opponents the mass meeting which together with the presentation of the petition was to take place in the vicinity of the Houses of Parliament shadowed forth the threat of a revolution. Its failure meant that normal conditions had been restored and caused the movement for the Charter to lose its drive.

However, it remains to be seen how far the view that the movement entered on a rapid decline after ' 48 has not been conditioned by wishful thinking on the part of the intimidated anti-Chartists and by subjective feelings of disappointment on the part of the overeagerly hoping champions of the movement. The first historian of the movement Gammage finds in the years from ' 48 to ' 54 only an afterglow of the former glory, and his tradition has been continued with hardly any modification, at least on this issue, by later authors. Only Julius West in his book, published posthumously in 1920, underlines the importance of this later period which, in its resistance against the stamp duty on papers, has gone full circle.

A short note by Jones, undoubtedly the principal figure among the Chartists in the fifties, lends a new interest to the above-formulated question concerning the importance of the later years of the Chartist Movement.

Jones refuses to speak at a conference of Holyoake and his circle who wanted to proceed with an agitation for the suffrage 1). In Jones' opinion the National Charter Association

1) In the collections of the Institute is a copy written by Holyoake himself of the very short invitation he sent to Jones on May 5th, 1856. It seems that there had been a preliminary meeting of only a few persons. 
which he controlled was the only real political power in favour of reform. He shows great confidence that their victory will be close at hand. Perhaps this proud attitude gives us some reason to criticise the current under-estimation of this last Chartist period and also to rate at its true value the opinion of Jones himself.

In the literature on the subject it is the custom to demonstrate the degeneration of the whole reform-movement by pointing to the great number of organizations, groups and associations that entered the field of 'reform' in the 50ies. There were, for instance the Left-wing Liberals, who were opposed to the Statutory Liberals of Palmerston and among whose representatives the receiver may be counted; and there were the wrangling groups of emigrants among whom naturally an internationalist inclination was the distinctive feature, and from whose midst the so-called First International was to rise eight years later. There were the National Charter Association who boasted that they had been the first afield (The N.C.A. was founded in 1840), and the National Reform League founded in ' 50 by O'Brien. The leaders of the N.C.A. were in touch with many of these and other groups, and were also personally involved in various attempts to form organisations. The Mass Movement of ' 54 and the International Committee of the following year point in this direction.

Such a variety of organisations however had been a feature of the older reform movement, and it is not therefore in itself a sign of degeneration, although it is a sign of weakness and of little direct urgency for action. In addition it appears that some of these associations were founded by people who were also active in other organizations, so that these groups cannot be said to be due to the disintegration that usually attends decadence.

It is true that the fresh development in Chartism since the conference at Manchester in May ' 52 where Jones became the most influential man on the new Executive Committee of the N.C.A. lacked the united front that was found in traditional historiography a characteristic of the early 
period of the Charter. But even at that time the number of currents was great. The difference lies in the fact that the earlier movement had reached some culminating points towards which the events could be said to have coursed before, and away from which they may be considered to have flown afterwards. But even though it lacked such a turning point the movement of the 50ies is important in itself.

It is a question of a different nature whether this objective importance agrees with the subjective bias of Jones in his letter to Holyoake of May 1856.

Is there any reason for his high estimation of the National Charter Association, and his opposition against the formation of another organisation probably of the same sort?

He had himself assisted in the foundation of some other organisations and we cannot therefore assume him to have by nature opposed all people uniting, even if in a different way, for the same purpose. This points without doubt to Jones' desire to find a specific form enabling him to extend the field of activity beyond the narrow group of his faithful supporters while maintaining his grip on them by means of his own organisation. Aiming at this twofold purpose Jones could not always steer a straight course. On the one hand he offers resistance whenever a "parallel" organisation threatens to cross his path, on the other hand he himself is active in other associations and movements.

The first named attitude we find for instance in '55 when the socalled Welcome and Protest Committee wanted to convert itself into a "Social and Democratic Organisation". It was Jones who opposed this on the ground that it would impede the development of his "newly founded Chartist Party" 1). This attitude is in keeping with his conduct in May '56, and although there are no data available to confirm this, we may assume that he did not change his position in connection with the proposal of fusion made at the instigation of $O$ 'Brien in the summer of the same year.

On the other hand he was not the man to be the leader

1) This name is only used by Rothstein, From Chartism to Labourism, p. 169, ed. 1929. 
of a strait-laced revolutionary organisation as the rupture with Marx which had been in evidence as early as 1855 shows. Jones who had originally been very close to Marx was still further shrinking from radical extremes and still more open to a wide organisation in '58 when his "The People's Paper" became the organ of the newly founded Political Reform League, which had only a moderately Chartist Programme catering for the middle classes.

In short Jones was trying to find the right path for himself and his movement during the fifties. In connection herewith and stating that Holyoake belonged to the more conservative wing of the movement, it is possible to see in his rejection of his former fellow-Chartist and his "reformers" a delimitation from this conservative side.

Was this intermediary position a tactical move with the purpose of keeping in touch with both wings so that later they might merge in one organization; and was the assurance of the coming victory which appears from the letter under discussion based on that policy? This is no more than a supposition which will perhaps be confirmed or invalidated when a comprehensive study on Jones, or his diary, which is preserved at Manchester, should be published. It is perhaps the very under-estimation of the rather ineffectual activity of the social movement in the interim period of the 50 ies and 60ies that has held the interest away from Jones.

Jones was a much-disputed figure. Of course he was both blamed for being a mercenary egoist and praised for his self-sacrificing generosity. There is also some uncertainty as to his attitute within the movement of which he was the leader. Whereas Marx on the occasion of Jones' death wrote to Engels about him as the only Labour leader who had understood their ideas, barring a few departures towards the right, there is a letter by Jones of '67-two years before his death-in which democracy is defined as a rule not by one class only, but by all parties moderating and counterbalancing one another ${ }^{1}$ ). This is anything but Marxism. But

1) Frederick Leary, Ernest Jones, 1887, p. 72. G. D. H. Cole does not mention this book in his "Chartist Portraits". 
on a previous occasion Jones turned against Lovett for a similar conception of democracy!

Was he then only a tactician bent on political power which he could best assert in the later years of his life with the support of the moderate group who might return him to the House of Commons? And is then that haughty rejection of Holyoake's invitation an expression of self-glorifying display of political power? Not a month before the rebuff of Holyoake Marx wrote about Jones to Engels.

„Du wirst wissen, dass Jones, mit Finler als Schatten, sich zum Diktator des Chartismus proklamiert hat und eine neue Organisation eingerichtet hat, die, indeed, im Wachsen begriffen ist, andererseits aber auch grossen Sturm und Entrüstung gegen ihn hervorrufe 2). (April 1st. 1856).

In this quotation we find a reflection not only of the element of personal assertion of political power, but also the optimistic and at first so strangely affected tone of the letter to Holyoake.

The course of history destroyed his power and his hopes soon afterwards. Yet they are not less worth mentioning than if his attempts had been crowned with success.

Fr. de J.

LETTER FROM JONES TO HOLYOAKE 4 pp. ca. $12 \times 20 \mathrm{~cm}$. (paper mark:

fleur-de-lis in

circle, embossed)

143, Strand,

May 7, 1856

Dear Sir,

In answer to the invitation you were kind enough to forward me, to attend a Meeting of Reformers at Anderton's Hotel, this evening, I beg to observe:

That I cannot see the utility of forming any new association. One, allsufficient in its principles and in its details for action is already and has long been in existence,- the National Charter Association. If the gentlemen who assemble tonight adopt the Charter in its entirety, they

2) You will know that Jones, with Finler as his shadow, has proclaimed himself dictator of Chartism and has founded a new organisation which is indeed increasing, but which is on the other hand stirring up a storm of indignation against him. 
cannot do better than enroll themselves under the banner of the Chartist Movement; if they do not adopt the Charter in its entirety, the people will never enrol (!) themselves under theirs. In either case the movement proposed as a separate movement would be a failure and a mistake.

I should be, for me, compelled to oppose it if for anything less than the Charter-and, if for the Charter, under some different name and organisation, it could only do mischief, as tending to divide that popular strength, which ought now, more than ever be united.

The Chartist body is the only powerful political organisation in existence, and one, which experience must have taught you, no separatist movement can successfully oppose, from whatever class it may emanate. -The Chartist organisation is now rapidly progressing towards national ascendancy, and the hour of its final victory is, you may rest assured, very near at hand. Under these circumstances I cannot see any utility in my attenting your meeting. Your Faithff.

Ernest Jones.

Vertically in the

margin last page bottom:

left: G. J. Holyoake Esq.

right: I should wish this letter read at your meeting. 
- argané. lér un exis bun acel me, w bit' en fercice

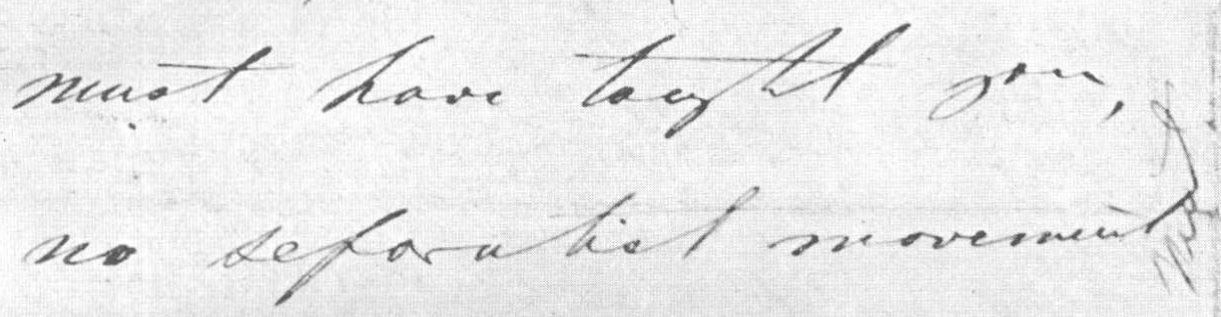
can oucefofalfolot, from wha buer clafe it may emanate. - Th OAd bitas

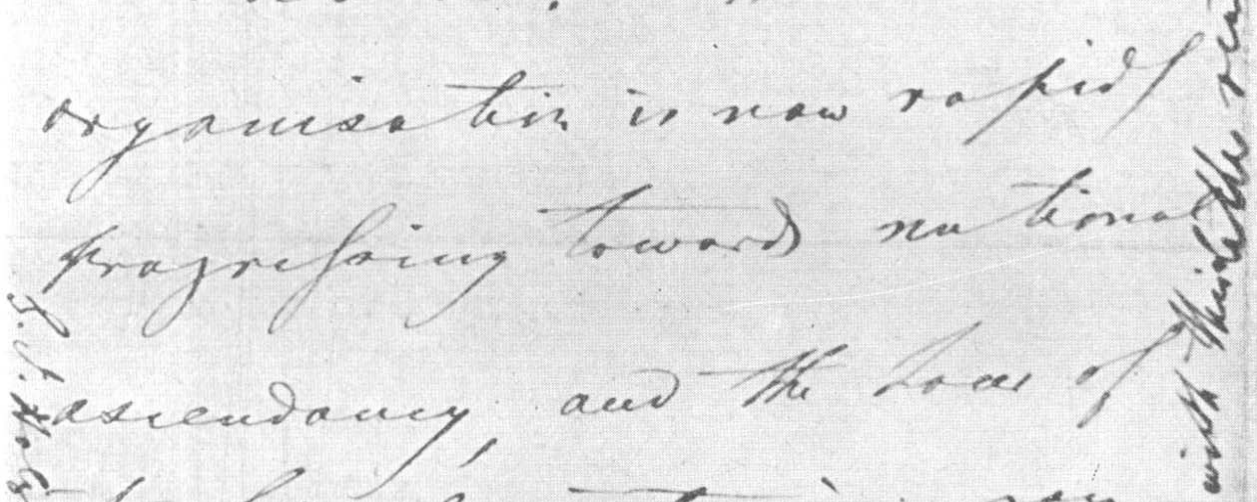
it final vatar in yen sug reat afowas, very nea

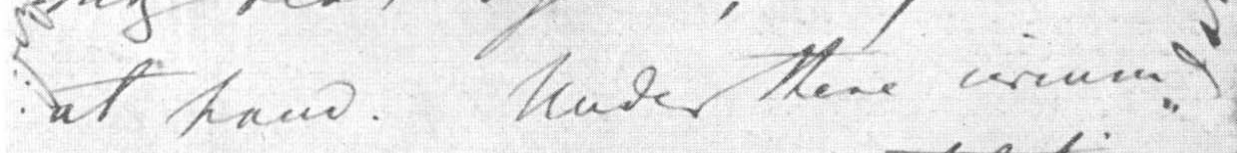

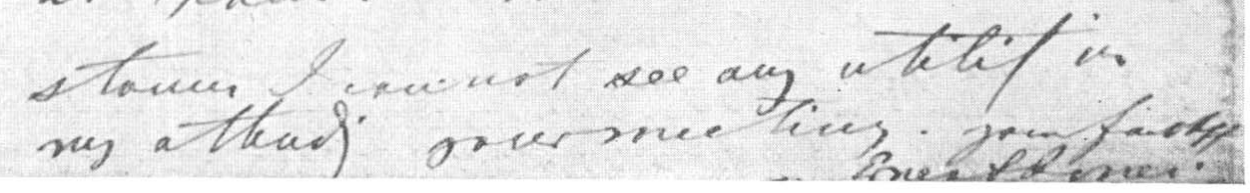

https://doi.org/10.1017/S0921254X0000057X Published online by Cambridge University Press 